\title{
Restoring ion channel pathology by parameter optimization
}

\author{
Jenny Tigerholm ${ }^{1,2^{*}}$, Erik Fransén ${ }^{1,2}$ \\ From Twentieth Annual Computational Neuroscience Meeting: CNS*2011 \\ Stockholm, Sweden. 23-28 July 2011
}

In diseases of the brain, the distribution and properties of ion channels display deviations from healthy control subjects. We studied two cases of ion channel alterations related to epileptogenesis. The first case of ion channel alteration represents an enhanced sodium current, the second case addresses the run down of conductance of the transient potassium current, $\mathrm{K}_{\mathrm{A}}$. In previous studies we have shown that $\mathrm{K}_{\mathrm{A}}$ reduce highly synchronized synaptic input while minimally affect semi-synchronized input (1). The $\mathrm{K}_{\mathrm{A}}$ channel may therefore function as a protective mechanism against synchronous input involved in seizures. In this study we investigate if modulatory substances which targets the $\mathrm{K}_{\mathrm{A}}$ can functionally corrected the two pathological models.

\section{Methods}

We used a detailed compartmental model of a CA1 pyramidal cell based on a model published by Poolos et al 2002 (2). The model includes sodium, delayed rectifier potassium, A-type potassium and h channel models. On three medial distal dendrites 20 excitatory synaptic inputs were placed. The 20 synaptic inputs had a temporal distribution with different standard deviation corresponding to different levels of synchronicity. The modulation of $\mathrm{K}_{\mathrm{A}}$ by two substances, KChIP1 and DPP6, was implemented in the model from experimental data. These substances produce shifts of activation, inactivation and time constant curves. Relative concentrations of these modulators were controlled by a numerical optimizer which compared model output to predefined neural output which represented a normal physiological response.

\footnotetext{
* Correspondence: Jennytigerholmtige@kth.se

${ }^{1}$ Department of Computational Biology, School of Computer Science and

Communication, Royal Institute of Technology, Stockholm, Sweden

Full list of author information is available at the end of the article
}

\section{Result}

DPP6 and KChIP1 can functionally correct the two pathological models. Figure 1 shows spike activity during control conditions (blue) as well as spike activity for the pathological models (red). Top trace shows the spike activity produced by the reduced $\mathrm{K}_{\mathrm{A}}$ model and the bottom increased $\mathrm{Na}$ model. Note the strong reduction is spike activity in the control case for highly synchronized input $(0-2 \mathrm{~ms})$. In both the pathological models the $\mathrm{K}_{\mathrm{A}}$ current is not strong enough to suppress highly synchronized input. For the functionally corrected pathological models (dotted lines), the example when KChIP1 was used as a free variable (black) and when DPP6 was used as the free variable (green) for the optimization, are shown.

\section{Conclusions}

Our simulations show that an increase of KChIP1 or of DPP6 can functionally correct both pathological models' response to different levels of synchronized input. These modulatory substances could be beneficial in reducing

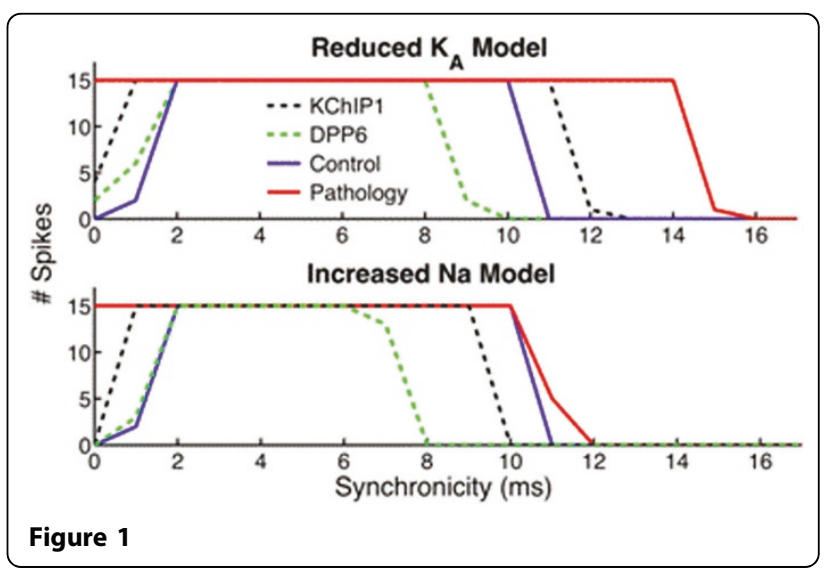


epileptic activity and could be candidates for drug development.

\section{Author details}

${ }^{1}$ Department of Computational Biology, School of Computer Science and Communication, Royal Institute of Technology, Stockholm, Sweden. ${ }^{2}$ Stockholm Brain Institute, Royal Institute of Technology, Stockholm, Sweden.

Published: 18 July 2011

\section{References}

1. Fransén $E$, Tigerholm J: Role of a-type potassium currents in excitability, network synchronicity, and epilepsy. Hippocampus 2010, 20:877-887.

2. Poolos NP, Migliore M, Johnston D: Pharmacological upregulation of $\mathrm{h}$ channels reduces the excitability of pyramidal neuron dendrites. Nature neuroscience 2002, 5:767-774.

doi:10.1186/1471-2202-12-S1-P334

Cite this article as: Tigerholm and Fransén: Restoring ion channel pathology by parameter optimization. BMC Neuroscience 2011 12(Suppl 1):P334.

\section{Submit your next manuscript to BioMed Central} and take full advantage of:

- Convenient online submission

- Thorough peer review

- No space constraints or color figure charges

- Immediate publication on acceptance

- Inclusion in PubMed, CAS, Scopus and Google Scholar

- Research which is freely available for redistribution

Submit your manuscript at www.biomedcentral.com/submit 